\title{
Negotiating Renewal-Option Clauses and How to Best Exercise Them - For Optometry Tenants
}

By Jeff Grandfield and Dale Willerton - The Lease Coach

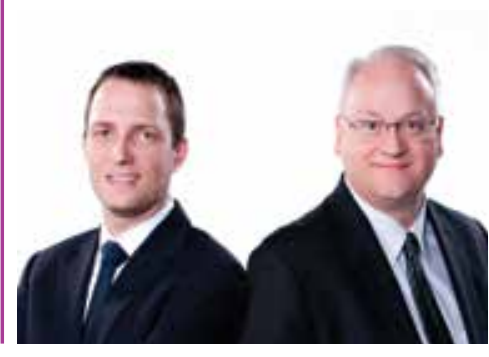

Dale Willerton is the founder of The Lease Coach and Jeff Grandfield recently joined him as partner. Dale and Jeff are commercial lease consultants who work exclusively for tenants, and are also professional speakers and co-authors of Negotiating Commercial Leases and Renewals For Dummies. Got a leasing question? Need help with your new lease or renewal?

Call1-800-738-9202,email DaleWillerton@TheLeaseCoach.com,orvisitwww.TheLeaseCoach. com. For a copy of our free CD, Leasing Dos \& Don'ts for Commercial Tenants, please email your request to DaleWillerton@TheLeaseCoach.com.
$\mathrm{R}$ Readers of our book, Negotiating Commercial Leases o Renewals for Dummies, will learn (in-part) that the renewal-option clause in a lease exists for the sole benefit of the tenant. Essentially, its purpose is to ensure that you're allowed to lease your space for another lease term - as long as you meet the predetermined conditions listed in your lease agreement. Not all landlords automatically include renewaloption periods or terms in their offer to lease or formal lease agreement. As an optometry tenant, it's your responsibility to request, insist on, or negotiate for renewal-option rights.

Most lease-renewal terms are the same length as the initial term. Therefore, if an optometry tenant signs an initial fiveyear lease term, it's common for the landlord to grant one five-year renewal-option period. Although there are no hard and fast rules, some landlords resist giving a renewal-option term that's longer than the initial term. The larger the financial investment you make in a location, the longer or more renewaloption terms you typically want or need to recoup your costs.

Remember that a renewal-option term for the tenant doesn't give the landlord any particular benefit. From your perspective, it may be better to have several short options terms, because longer may not be better for you. The renewal-option term in most lease agreements is for a set period of time (e.g. three or five years) and you must make a full-term commitment if you do exercise the renewal-option. Just because you have an initial lease term with a 10-year renewal-option, this may not be ideal for you. What if you plan to move, retire, or sell and only want to renew for just two years? In this case, you will have to forgo exercising the 10year option and negotiate for just two more years instead.

If you can persuade the landlord to agree to a renewaloption term that's up to five years as determined by the tenant, you can have maximum flexibility to exercise your renewal- option term, but potentially for a shorter period of time. Landlords typically resist this tactic because they want to retain as much control as possible. It costs you nothing to try for this up to clause, but it's not often that the landlord agrees.

The majority of lease agreements don't preset the rental rate for the renewal-option term for a couple of reasons:

- Landlords want to be able to maximize the return on their real estate investment. No one has a crystal ball, so the landlord is simply keeping options open for the maximum future rent increase possible.

- A landlord can constructively evict an undesirable tenant by simply dictating a much higher rental rate on the renewal term than is justified. When the tenant refuses to pay this increased rental rate and moves out, the landlord does a deal with a more desirable tenant.

As a result, most lease agreements will state that the rent for a renewal-option term is determined by fair market value. However, it is important there is a mechanism such as arbitration that determines how the fair market rents will be decided in the event the tenant and landlord cannot agree. This can help you avoid the constructive eviction noted previously.

A landlord might hedge his bets by including language in the renewal-option clause that states that under no circumstances (if the renewal-option clause is exercised) can the rental rate go down. If you've done your homework and determined that market rental rates have declined, then exercising the renewaloption clause can actually work against you.

Though not common, presetting the rental rate for the renewal-option term in advance may be an alternative. In most cases, if the landlord agrees to preset the renewal term rental 
rate, it's usually at an artificially high rate which often makes it useless to the tenant. However, over a 10-year lease term, the country can undergo major positive economic changes which could make a preset rate work in your favor.

Annual increases can be determined in a number of ways:

- Preset annual increases for the renewal term are often calculated as annual percentage increases (e.g. 3, 4, or 5 percent). This means the rent is compounded by these annual percentage increases each year - regardless of what the market rental rate really is.

- Consumer Price Index (CPI) annual increases can also be used to calculate future rents. In some cases, a lease agreement states that the annual rental rate increase may be 5 percent or the rise in CPI, whichever amount is greater. So, if CPI goes down (or if the economy enters a period of deflation), the tenant's rent goes up anyway - if they exercised their renewal-option clause.

- Rental rates are a dollar figure. Some landlords set a one- or two-dollar-per-square-foot (for example) rent increase per year for the renewal term.

It's important to get the renewal-option clause wording right. Normally, the landlord constructs the actual wording of the lease renewal-option clause - often with plenty of forethought and deliberation. Other times, however, smaller landlords may use boilerplate lease agreements (provided by attorneys) which may or may not give careful consideration to the renewal-option clause. Landlords are accustomed to agreeing to renewal-option terms often fully loaded with clauses with takeaway conditions. Protectionist wording may, in fact, completely dilute the clause's benefit to you.

Here are some typical clauses or conditions a landlord may add to the renewal-option clause for his own benefit and/or protection - and why:

- Default (or uncured) default by the tenant, meaning nonpayment of rent or other non-material defaults, generally nullify the tenant's renewal-option rights. Even if a tenant corrects the default, it may too late to salvage the renewal-option clause rights.

- If the tenant wants to sell the business, the sale of the business and assignment of the lease agreement often render the renewal-option clause void. This is where the landlord states that the renewal-option clause is personal to the tenant and for the sole benefit of the original tenant - and not the person you sell the business to.
- Failure to hit certain sales volumes - especially if the landlord expects you to make percentage rental payments - can nullify the renewal-option clause. If the tenant is struggling, and their sales can prove it, the landlord may want to replace you with another tenant who has a better chance of paying percentage rent (or simply staying in business).

- If the tenant company/entity has a substantial change in shareholders, this can also render the renewal-option clause dead as this may be interpreted as a lease assignment.

Remember that all of these clauses can be negotiated with the landlord to soften or remove some of these conditions pertaining to your renewal-option clause.

Timing is important; most lease agreements state that the tenant has a specific window of time prior to the leaseagreement expiration within which they can exercise the renewal-option clause. Typically, this is 6,9 , or 12 months (but sometimes stated in a number of days instead) prior to the lease expiration date.

The majority of our clients do not exercise their renewaloption clause when we are negotiating their lease renewal. The reason this is the case is that we negotiate well in advance of the period that the tenant is required to provide notice to formally exercise their renewal-option clause. By doing this it allows us to not only find out the landlord's expectations prior to committing to a renewal term but also allows for the negotiation of free rent, tenant allowance, and/or further renewal options or other inducements as part of the renewal term. If a tenant simply exercises their renewal-option clause, all of these incentives are off the table and just the rent is left to be determined. Your renewal-option clause should be viewed as a safety net to ensure your tenancy if you felt that the landlord did not want to retain you as a tenant rather than your default plant o renew your lease.

With all this being said, how can optometry tenants properly exercise the renewal-option clause, if required?

- Discuss the renewal-option process with the landlord / landlord's property manager first so that you understand what is required of you.

- Know how far in advance to pull the renewal-option trigger. While most lease agreements state a deadline for exercising the renewal-option clause, they may also state that you can't exercise your renewal-option too soon. Typically, there is a 6-month window where this is possible; however, it can range from 6-12 months. 
- Understand the legal mechanics of exercising the option clause. Landlords aren't required to notify the tenant that their renewal-option window is approaching or closing. The tenant is solely responsible for keeping track of such important dates. Most landlords will accept a letter or an e-mail saying that you're exercising your renewal-option clause. Some other landlords may even accept your verbal representation. The key here is for you to get written confirmation from the landlord or property manager that they recognize and accept your renewal-option letter.

Finally, watch for a separate clause in your lease agreement stating how official notices must be sent and received by both the tenant and the landlord. This often includes a specific mailing address for the landlord (which can be different from where you send your rent check). When we exercise a leaserenewal option for a tenant, we will often do it in several simultaneous ways:

- Mail the letter to the landlord's official place of notice as a registered letter that produces a delivery receipt.

- E-mail or fax the same letter to the landlord or property manager.

- Mail the letter to the property manager by regular mail.

- Call the landlord, property manager or office secretary to ensure delivery - noting their name and title and time of call for follow-up and/or confirmation purposes.
For a copy of our free CD, Leasing Dos \& Don'ts for Commercial Tenants, please e-mail your request to DaleWillerton@TheLeaseCoach.com.

Dale Willerton and Jeff Grandfield - The Lease Coach are Commercial Lease Consultants who work exclusively for tenants. Dale and Jeff are professional speakers and co-authors of Negotiating Commercial Leases \& Renewals For Dummies (Wiley, 2013). Got a leasing question? Need help with your new lease or renewal?

Call 1-800-738-9202, e-mail DaleWillerton@TheLeaseCoach.com or visit www. TheLeaseCoach.com.
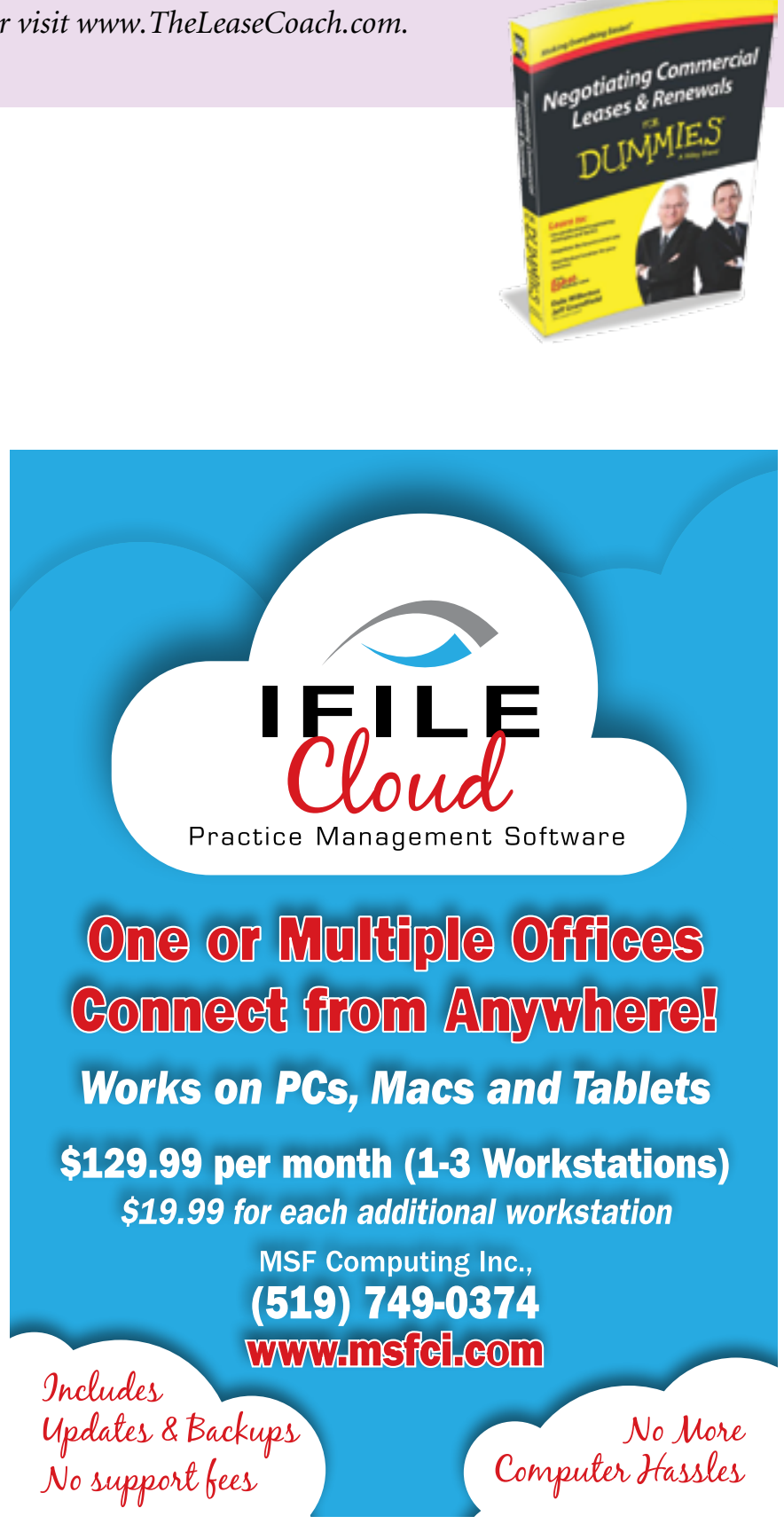